\title{
Anesthesia, cytokines and cancer recurrence
}

\author{
Yuji Kitamura ${ }^{1}$, Iolanda Di Biaso ${ }^{2}$, Pablo Mauricio Ingelmo ${ }^{1}$ and Gianluca Bertolizio ${ }^{1 *}$ \\ ${ }^{1}$ Department of Anesthesia, McGill University Health Centre, Montreal Children's Hospital, Montreal, QC, Canada \\ ${ }^{2}$ Instituto comprensivo “KOINÈ", Monza, Italy
}

\begin{abstract}
Cytokines are essential mediators for the regulation of both innate and acquired immunity and hematopoiesis. They modulate immune cell signaling, activation, adhesion and functioning. They regulate the individual response to several insults such as infection, inflammation, trauma, and pain. Moreover, the balance between pro-inflammatory and anti-inflammatory cytokines is critical for the evolution of surgical complications and tumor progression.

Several drugs, including anesthetic agents, influence cytokines secretion. Opioids, inhalational agents, intravenous and local anesthetics have shown different effects on immune system and cytokine expression. Therefore, anesthesia may play an important role in postoperative recovery and outcome of cancer patients.

The aim of the present article is to review the main role of some important cytokines and the effect of anesthesia techniques and drugs on their secretion. Furthermore, current clinical evidence regarding the effects of anesthesia on cancer recurrence will be discussed.
\end{abstract}

\section{Cytokines and immune system}

Cytokines are proteins expressed in both innate and acquired immune system and are often named according to the secreting cells (i.e., lymphocytes, interleukins, etc.). They are essential mediators of the natural (non-specific, innate) immunity, which is the initial step of the inflammatory response. They also play a pivotal role during the specific immunity, which occurs after exposure to antigens, as they regulate lymphocyte and leukocyte activation, growth and differentiation, and the immune-mediated inflammation [1].

The cytokines have different structures, but also common aspects, which are summarized in Table 1.

The aim of the present article is to review the main role of some important cytokines and the effect of anesthesia techniques and drugs on their secretion.

\section{Cytokines receptors}

The cytokines receptors are formed by one or more transmembrane proteins: the extracellular portion binds the cytokine, whereas the cytoplasmic part starts the signal cascade. Based on the extracellular portion, they are divided in five categories.

1) Type I receptors, which have four $\alpha$-helical stands and contain four cysteine residues and the amino acid motif tryptophanserine-X-tryptophan-serine (WSXWS).

2) Type II receptors, structurally similar to Type I receptors, but without the sequence WSXWS.

3) Interferon receptors, which have domains rich of cysteine and can induce apoptosis or stimulate gene expression;

4) Immunoglobulin receptors, which have extracellular domain for immunoglobulins (Ig) and different mechanisms for single transduction;

5) Seven-transmembrane spanning family receptors, which pass the membrane seven times and transduce the signal through G-protein pathway.

\section{Cytokines function}

Provided that the same cytokine may be produced during both innate and acquired immunity response, cytokines can be classified according to their functions:

1) Cytokines regulating the innate immunity and secreted by stimulated macrophages;

2) Cytokines regulating the acquired immunity and secreted by lymphocytes;

3) Cytokines stimulating the hematopoiesiss and secreted by bone marrow, leucocytes and other cells.

Table1. Common aspect of cytokines.

Common aspects of Cytokine

Their secretion is brief and limited in time

They have pleiotropic properties, because they have the same effect on multiple cells

They may affect other cytokines

They may have autocrine, paracrine or endocrine function

They bind specific receptor on the membrane

The expression of their receptor on target cells is regulated by signals that are outside the cell The targeted cell responds with phenotype modifications and acquisition of new functions

Correspondence to: Gianluca Bertolizio, Department of Anesthesia, McGill University Health Centre, Montreal Children's Hospital, Montreal, QC, Canada, E-mail: gianluca.bertolizio@mcgill.ca

Key words: cytokines, general anesthesia, regional anesthesia, surgical stress and cancer

Received: May 24, 2015; Accepted: June 28, 2015; Published: July 03, 2015 


\section{Cytokine expressed during the innate immunity response}

\section{Tumor necrosis factor (TNF- $\alpha$, TNF- $\beta$ )}

The TNF is responsible for the initial phase of acute inflammatory response, especially against Gram-negative bacteria. It exists in two forms, $\alpha$ and $\beta$, which have similar effects and equally bind both forms of the TNF receptor (TNFR-I and TNFR-II).

It is mainly produced by mononuclear phagocytes after bacterial infection (i.e., after contact to LPS), but it can also be secreted by T-lymphocytes, natural killers (NK) cells and mast cells [2].

T-Lymphocytes and NK cells, trough INF-y secretion, augment TNF synthesis. In general, TNF- $\alpha$ promotes the recruitment of neutrophils and monocytes thought the expression on the endothelial surface of specific receptors. It also increases the body temperature (stimulating the hypothalamus along with IL-1) and the amyloid A protein concentration in the hepatocytes (similarly to IL-6 and IL1 ), and promotes the secretions of prostaglandins, platelet-activating factor (PAF), glucocorticoids and eicosanoids [3].

At high concentrations, it is responsible for cachexia (loss of muscular and adipose tissue) [4], certain autoimmune disorders [5], and the decrease of myocardium contractility and vascular tone, which cause cardiovascular collapse in sepsis [6].

\section{Interleukin-1 (IL-1)}

The IL-1 is synthesized by mononuclear phagocytes in response to bacterial infection and other cytokines, such as TNF. It is also secreted by neutrophils, macrophages, epithelial and endothelial cells [7]. Like TNF, IL-1 is an important mediator of the inflammatory response [8]. Both IL- $1 \alpha$ and IL $-1 \beta$ bind the same receptor and have the same function, but only IL- $1 \beta$ is secreted active. Two receptors associated to IL-1 exits: IL-1RI, expressed by almost all cells, and IL-1RII, present on the B-lymphocytes surface. The IL-1R does also exist in soluble form. At low concentrations, IL-1 promotes leukocytes adhesion, stimulates T-lymphocytes, B cells, macrophages, and causes the release of prostaglandins, IL-6, IL-8 and tissue factor III. At high concentrations, IL-1 induces fever, muscular and adipose catabolism and anorexia [9]. The IL-1ra represents the receptor antagonist and has the function of endogenous autoregulation of IL-1 activity [10].

\section{Interleukin -6 (IL-6)}

It is pro-inflammatory molecule and it is produced by mononuclear phagocytes, endothelial cells, and fibroblasts in response to several stimuli, such as LPS, IL-1, IL-2, TNF, INF, platelet-derived growth factor and viruses. During the innate response, it stimulates the acutephase proteins, whereas it promotes the B-lymphocytes growth when specific immunity is initiated. It also plays a role in hematopoiesis and it has been shown to have anti-inflammatory properties [11]. Furthermore, it is involved in diseases such as lupus erythematous and rheumatoid arthritis [12]. The IL-6 binds the receptor IL-6R, which has a soluble form.

\section{Interleukin-8 (IL-8)}

It is a potent chemoattractant and activator of neutrophils [13], and it has been implicated in cardiopulmonary bypass injury [14] and multiple organ failure [15].

\section{Interleukin-10 (IL-10)}

It is a potent anti-inflammatory cytokine and it is mainly produced by activated macrophages and T-lymphocytes. It has an inhibitory effect on macrophages activation and TNF production [16]. Therefore it has a pivotal role in regulating the immunity response [17-18].

\section{Interleukin-12 (IL-12)}

It is mainly produced by mononuclear phagocytes and dendritic cells, and it is involved in both innate and acquired immunity response [19]. Intracellular bacteria, viruses, activated T-helper lymphocytes and INF-y promote IL-12 production. IL-12 stimulates NK cells, lymphocytes $\mathrm{CD}^{+}$and the differentiation of lymphocytes $\mathrm{CD}^{+}$in $\mathrm{T}$ helper type1 (Th1). In particular, Th1 produce INF-y, which activates macrophages.

\section{Interleukin-15 (IL-15)}

It is produced by mononuclear phagocytes in response to viral infections and LPS. It promotes the early NK cells expansion [20], and induces IL-8 production, NF- $\mathrm{KB}$ and fungal phagocytosis [21].

\section{Interleukin-18 (IL-18)}

It is produced by macrophages after contact to LPS and promotes the production of INF-y from NK cells and T-lymphocytes and it is involved in gram-positive sepsis [22]. Its pro-inflammatory effect is synergic to IL-12 [22].

\section{Interferons (INF- $\alpha$ and INF - $\beta$ )}

The INF- $\alpha$ is mainly produced by mononuclear phagocytes, whereas INF- $\beta$ is secreted by several cells, including fibroblasts. They have an important role during the early innate response to viral infections. In particular, they promote the cytotoxic action of lymphocytes $\mathrm{CD} 8^{+}$and the production of Th1.

\section{Chemokines}

They are a family of cytokines produced by several cells, such as endothelial and epithelial cells, and fibroblasts [23]. They mainly promote lymphocytemigration.

\section{Cytokine expressed during the specific immunity response}

\section{Interleukin-2 (IL-2)}

It is produced by lymphocytes $\mathrm{CD}^{+}$and lymphocytes $\mathrm{CD} 8^{+}$ [24], and it is considered the main autocrine and paracrine growth factor for T-lymphocytes. It is responsible for clonal expansion and T-lymphocytes differentiation, as it promotes the development of cytotoxic Th1, and stimulates the production of IL-4, TNF- $\alpha$ and INF-y [25]. Moreover, it promotes the proliferation and the activation of other immune cells, such as NK cells, neutrophils, macrophages and B-lymphocytes. On activated T-lymphocytes, however, it also has a pro-apoptotic function [26] to stop their inflammatory action. It binds the receptor IL-2R, which is formed by subparts $\alpha, \beta$, and $\gamma$. The IL$\mathrm{R} 2 \alpha$ exists in soluble form.

\section{Interferon y (INF-y)}

It is produced by macrophages, NK cells, T-lymphocytes $\mathrm{CD}^{+}$ Th1 and $\mathrm{CD}^{+}$. It stimulates T-lymphocytes and NK cells, which activate both macrophages and antigen-presenting cells, and promotes 
the T-lymphocytes differentiation in Th1, counteracting the effects of IL-4 [27].

\section{Interleukin-4 (IL-4)}

Lymphocytes $\mathrm{CD}^{+} \mathrm{T}$ helper type2 (Th2) represent the main source of this cytokine, which is responsible for IgE production and Th2 differentiation [28]. It also counteracts INF-y on macrophages by downregulating IL-1, TNF- $\alpha$, IL - 6 , and IL- 8 and therefore limiting the cell-mediated response.

\section{Interleukin-5 (IL-5)}

It is produced by lymphocytes $\mathrm{CD}^{+} \mathrm{Th} 2$ and activated macrophages. Its main function is the promotion of eosinophil proliferation and differentiation, the proliferation of B-lymphocytes and the IgA production.

\section{Interleukin-13 (IL-13)}

It is produced by lymphocytes $\mathrm{CD} 4^{+} \mathrm{Th} 2$ and some epithelial cells. Like IL-4, it expresses anti-inflammatory effects on macrophages, monocytes and B-cells, where it counteracts INF-y, but not on T-lymphocytes [29]. It also stimulates IL-1ra [30].

\section{Transforming growth factor- $\beta$ (TGF $-\beta$ )}

It is produced by several immune cells and has an immunosuppressive action, like IL-10 and IL-4. In fact, it inhibits the proliferation and the differentiation of T-lymphocytes and macrophages.

\section{Cytokine that promote the hematopoiesis}

The principal cytokines involved in the hematopoiesis are IL-3, involved in immune cells differentiation, the stem cell factor (SCF), involved in stem cells differentiation and proliferation, IL-7, involved in bone marrow production of lymphocytes, and the granulocytemacrophage colony-stimulating factors (GM-CSF, M-CSF, and G-CSF), involved in bone marrow production of leukocytes and delayed apoptosis of macrophages and neutrophils [31]. It is beyond the scope of this review to describe their function.

\section{Anesthesia and cytokines}

Immunity can be affected by anesthesia [32-34], surgical stress [34-38], surgical techniques [39], and postoperative pain [34,40]. Each anesthetic agent has different effects on the immune system [36,41,42] and therefore the type anesthesia may play a role in postoperative recovery [42] and even in cancer recurrence $[43,44]$.

\section{Inhalational anesthetics}

Since inhalational anesthetics were brought into clinical use in the $1840 \mathrm{~s}$, research has been focused in finding the ideal agent, which offers smooth induction and stable maintenance of general anesthesia with minimal adverse effects $[45,46]$. Halogenated agents such as isoflurane, sevoflurane and desflurane are currently used to provide inhalational general anesthesia. Several studies have shown dosedependent inhibitory effects of halogenated anesthetics on both innate and humoral immune system [42].

Halothane, enflurane, isoflurane and sevoflurane inhibit neutrophil production of reactive oxygen species (ROS), suggesting that volatiles impair a critical step of the inflammatory response [47-49]. Additionally, they have shown to increase the expression of inducible NO synthase (iNOS), which plays a role in the induction of NO release from macrophages and may have protective effects during the inflammatory reaction [50-51].

Isoflurane, sevoflurane and desflurane are associated with a significant increase of pro-inflammatory cytokines IL-1, IL- 8 and TNF- $\alpha$ in alveolar cells [35,52-54]. They also inhibit lymphocyte proliferation and the release of IL- $1 \beta$ and TNF- $\alpha$ in peripheral blood mononuclear cells (PBMC) [55-56]. Similar results have been confirmed in children [57-58]. Halothane suppresses the activity, but not the number, of NK cells and promotes the retention of breast cancer metastasis in rats [59]. Isoflurane significantly decreases the Th1/Th2 ratio in humans [35] when compared to intravenous anesthetics; it also decreases circulating NK cells and increases B-lymphocytes, IFN-y, IFN- $\alpha$, TNF- $\alpha$ and IL-2 [60].

Furthermore, inhalational balance anesthesia with sevoflurane is associated with higher IL-6 concentrations and more depressed T-lymphocyte cells $\left(\mathrm{CD}^{+}, \mathrm{CD}^{+}, \mathrm{CD}^{+}\right)$, activation markers $\left(\mathrm{CD} 25^{+}\right.$, $\mathrm{CD} 26^{+}$, and $\mathrm{CD} 9^{+}$) and HLA-DR molecules, in comparison to total intravenous anesthesia (TIVA) [38]. Nitrous oxide has shown to impair neutrophil chemotaxis and function and mononuclear cell production [61], and DNA synthesis [43]. In animals, it promotes lung and liver metastasis [62], but this effect has not been proven in humans [62]. Recently, the immunomodulation of new anesthetic agent xenon has been investigated [63]. Xenon is an odorless noble gas, normally present in traces in Earth's atmosphere, and it has been used as volatile anesthetic [64]. It has shown hemodynamic stability, fast recovery and neuroprotective proprieties but high costs [65].

In vitro investigations suggest that xenon has pro-inflammatory effects, increasing TNF- $\alpha$ and IL-6 [66], and IL-1 $\beta$ [67] in LPSmediated cultures. A recent study on adults did not show any differences in leucocyte function in peripheral blood with xenon compared to sevoflurane [63].

\section{Intravenous anesthetics}

The modern intravenous anesthesia began in the 1930s with the introduction of barbiturates into the clinical practice, such as thiopental [68]. Benzodiazepines, like diazepam and midazolam, are GABA agonists with sedative, hypnotic, anxiolytic, anticonvulsant, and muscle relaxant properties; they are commonly used in premedication or for sedation in minor procedures $[69,70]$. Ketamine acts on NMDA receptors, and differs from other anesthetics because of its strong analgesic effect with minimal respiratory depression [71,72]. Etomidate is a GABA agonist used for induction of general anesthesia and sedation, and presents peculiar characteristics, such as adrenocortical suppression [73-75].

Propofol is a hypnotic and amnestic agent, used for both induction and maintenance of general anesthesia TIVA, and short procedures [76,77]. Dexmedetomidine is a $\alpha 2$-adrenoceptor agonist, which induces sedative state similar to physiological sleep $[78,79]$. Several studies have shown that propofol impairs neutrophil, monocyte and macrophage functions. Propofol inhibits iNOS expression from macrophages and suppresses NO generation [80-82]. Other antiinflammatory effects of propofol have been observed in LPS-stimulated macrophages [83].

On the other hand, some investigations on healthy subjects suggest that propofol has no inhibitory effect on lymphocytes [84-86], neutrophils [87] and phagocytes [88] function. Similarly, propofol does not show significant inhibition of neutrophil function in severe brain injury patients [89]. Propofol and midazolam decrease the 
level of extracellular IL-8 from lipopolysaccharide (LPS)-stimulated neutrophils, although intracellular IL-8 and mRNA levels increases [90]. This suggests that these agents affect the cytokine release at the post-translational level.

Propofol also inhibits the production of IL-10, TNF- $\alpha$, IL-1 $\beta$ and IL-6 in LPS-stimulated peripheral blood mononuclear cells (PBMCs) [91], probably acting at the pre-translational level [81]. In endotoxinexposed rats, propofol, but not ketamine, blunts the TNF- $\alpha$ response; on the other hand, both drugs have inhibitory effect on the increase of IL-6 and IL-10 [92]. Other studies have shown that propofol inhibits IL-8 and increases the level of the anti-inflammatory cytokine IL-10, which blocks the pro-inflammatory cytokines and induces the release of IL-1 receptor antagonist $[85,90]$.

Propofol, like halothane, inhibits NK activity, but does not promote tumor retention in the lung [59]. A study showed different effects of propofol and thiopental on the $\mathrm{Th} 1 / \mathrm{Th} 2$ ratio by measuring the level of IFN- $\gamma$ and IL-4 in PBMC [93]. High doses of propofol increased the Th1/Th2 ratio (INF-y/IL-4), whereas low dose did not change INF-y, IL-4 and IL-2 [93]. However, another study showed no change in Th1/ Th2 ratio after propofol anesthesia [35]. Thiopentone, diazepam and ketamine have shown to negatively affect NK activity and lung tumor retention [59]. Thiopental and ketamine [94] also inhibit the LPSinduced release of IL-1, IL-6, TNF- $\alpha$ [95] and IL-8, and increase IL10 [96-97]. In healthy volunteers, thiopentone and etomidate impair lymphocytes function [84]. Thiopentone may have no effect on IL-2 [93], but it decreases INF-y [93,98], IL-4 [93] and INF-y/IL-4 ratio [93], and impairs chemotaxis [99] and phagocytosis $[88,99,100]$. Similarly, midazolam inhibits chemotaxis [99] and IL-8 secretion [90].

Preoperative use of small doses $(0.15 \mathrm{mg} / \mathrm{kg})$ of ketamine has been shown to suppress the inflammatory response and release of IL-6 and TNF- $\alpha$, without altering IL-2 secretion [95]. Etomidate causes inhibition of T-lymphocyte function in vitro [101], but other studies have shown that etomidate does not affect NF-kappa B activation in human T-lymphocytes [102]. Etomidate increases IL-10 concentration and inhibits the release of IL-1 receptor antagonist after LPSstimulation in cultured human whole blood [85].

Dexmedetomidine, $\alpha$ 2-adrenoceptor agonist, has no effect on neutrophil functions in vitro [103]. On the other hand, dexmedetomidine has been shown to increase Th1/Th2 cytokine ratio in patients undergoing laparoscopic surgery [104]. Preemptive administration of dexmedetomidine also suppresses the cytokine response after LPSinduced endotoxemia in murine model [105].

\section{Opioids}

Opioid are a family of drugs that binds opioid $\delta$, and $\kappa$ receptors such as $\mu[106,107]$. They are commonly distinguished in natural (opiates), such as morphine, and synthetics, like fentanyl, remifentanil, alfentanil and sufentanil. The activation of opioid receptors produces multiple effects, such as sedation, analgesia and respiratory depression [107]. It is known that opioid receptors are also expressed on immune cells [108]. The suppressive effects of opioids on immune system have been well established [109]. In the late $19^{\text {th }}$ century, it was reported that phagocytosis function of leukocytes were inhibited by opioids [110] Opioids are considered to exert the immunosuppressive effects through specific receptors expressed in the nervous system and immune cells $[111,112]$.

The activation of these receptors in the nervous system leads to the release of glucocorticoids and catecholamines, which suppress the peripheral immune response $[113,114]$. Furthermore, the stimulation of opioid receptors immune cells causes the suppress of their functions, including cytokine production [115]. Morphine inhibits neutrophil, monocyte, macrophage and lymphocyte functions. The suppressive effects of morphine may be mediated mainly by their $\mu 3$ opioid receptor, which influences NO release and inhibits NF- $\kappa$ B pathway and the production of pro-inflammatory molecules [116]. Studies have shown that morphine inhibits IL-10 and IL-2 production from monocytes and macrophages [117]. Morphine supresses IFN- $\gamma$ and IL-2 production of T-lymphocyte [117]. In addition, chronic administration of morphine causes a decrease in Th1/Th2 ratio, as the cytokine balance shifts from Th1 cytokines (IFN- $\gamma$, IL-2) to Th2 cytokines (IL-4) [118]. Compared to morphine, synthetic opioids such as fentanyl, remifentanil, sufentanil and alfentanil seem to have minimal or no immunosuppressive effects [32]. This difference may be secondary to the $\mu 3$ receptor, which is not bind by synthetic opioids such as fentanyl [119]. Although suppressive effects of fentanyl on NK cell have been reported in animals [120], in humans it has shown that fentanyl increases activity and number of NK cells, and $\mathrm{CD} 8^{+}$cytotoxic T-lymphocytes [121]. However, neither polymorphonuclear cells (PMNC) activity [122] nor cellular adhesion is affected [123]. Moreover, fentanyl has no effect of on the release of cytokine [85]. Clinical dosage of fentanyl and remifentanil do not change the concentration of IL-6, TNF, IL-10 and IL-2 [124], but remifentanil has been shown to attenuate the postoperative increase of IFN- $\gamma / \mathrm{IL}-10$ ration of greater extent than fentanyl [124].

\section{Local anesthetics}

Local anesthetics, such as lidocaine, bupivacaine and ropivacaine, are drugs that block the nerve conduction, causing sensory and/ or motor loss. They act through the inhibition of $\mathrm{Na}^{+}$channel on the nerve membrane [125]. They can be administered peripherally (local infiltration, topical application, plexus block), or at level of the spine (epidural and spinal anesthesia) [126,127]. Lidocaine can be also given intravenously exerting analgesic effects [128]. Several studies have investigated the effect of local anesthetics on immune system.

In vitro, lidocaine inhibits the IL- 8 and IL- $1 \beta$ release $[129,130]$ from epithelial cells, the IL-1 $\beta$ secretion from mononuclear cells and neutrophil function [130], the phagocytosis [130,131], and the migration of leukocytes $[130,132]$. It attenuates the formation of reactive oxygen metabolites [133], and the release of leukotrienes, IL$1 \alpha$ [134], and histamine [135]. Similar effects have been demonstrated with bupivacaine and ropivacaine [130,131,136,137].

Lidocaine also inhibits interferon-inducible IL-10 secretion in intestinal epithelial cells [138], attenuates IL-1 $\beta$, IL -6, IL-8 and ICAM-1 on activated human umbilical vein endothelial cells [139], and impairs the secretions of IL-2, TNF- $\alpha$, INF- $\gamma$ [140]. Furthermore, in animals with LPS-induced lung injury, lidocaine attenuates the release of TNF- $\alpha$ and IL -6 [141], whereas ropivacaine reduces the expression of ICAM-1 and the leukocyte adhesion [142]. Local anesthetics are used to perform peripheral and central blocks, which can be an adjuvant of general anesthesia or used as sole type of anesthesia. Therefore, beside the direct effect on the immune system, local anesthetics affect the immunity by blocking the sympathetic nervous system and by attenuating the surgical stress $[32,36]$.

The combination spinal/epidural anesthesia has been shown a significant reduction of postoperative cortisol peak with respect to general anesthesia [143]. This effect has been confirmed after several major surgeries [144]. Similarly, epidural anesthesia preserves NK cell cytotoxicity after abdominal surgery with respect to general anesthesia 
alone [145]. Finally, epidural anesthesia, but not general anesthesia, has shown no impairment of cytokine production [146].

\section{Does the type of anesthesia influence the risk of cancer recurrence? Clinical evidence}

Intraoperative tumor disruption, decrease antiangiogenic factors, augmentation of growth factors and surgery-related immunosuppression have been proposed as surgical factors promoting cancer recurrence [34].

Most of the studies that investigated the influence of anesthesia on cancer recurrence have been done in animals.

Clinical studies regarding the effect on anesthesia and analgesia techniques on the immune function are lacking [34,44]. Interest has been focused to local anesthesia (peripheral and central blocks), which has shown beneficial effects on immunity after surgery [147] and may affect surgical outcome of oncologic patients [43,148-150]. Regional anesthesia is believed to be beneficial against cancer recurrence due to reduced exposure to immunosuppressive agents (i.e., nitrous oxide), reduced surgical stress and adrenergic stimulation, but the mechanism is still unclear [147]. In fact, in absence of surgical stress, both general and local anesthesia have minor and transient effects on immune function [151].

On the other hand, cancer proliferation involves several stimuli and mediators, which can be all affected by the anesthetics [147,152].

NK cells activity was investigated in patients undergoing laparotomy colectomy under either general anesthesia or epidural anesthesia alone [145]. Patients receiving general anesthesia had a significant reduction of NK cells activity $(36 \% v s .22 \%, \mathrm{p}=0.02)$ respect to preoperative values, whereas the epidural group did not shown significant changes. Moreover, postoperative stress biomarkers (plasma and epinephrine and cortisol levels, and urinary cortisol) were reduced in the epidural group only. However, in this study the surgical indications included both cancer and not cancer lesions, patients were randomized, and NK cells activity was not compared between groups, making the results questionable.

Patients undergoing surgical resection of non-small cell lung cancer, in fact, showed a postoperative decrease of percentage (13.07 $\pm 9.81 \%$ vs. $9.6 \pm 6.57 \%$ compared to preoperative values, $\mathrm{P}<0.001)$ and function $(31.61 \pm 21.96 \%, 13.61 \pm 9.36 \%$ compared to preoperative values, $\mathrm{P}=0.001$ ) despite the use of epidural analgesia [153].

On the other hand, the association of general and epidural anesthesia demonstrated to attenuate the increase of IL-2 and to promote the return to baseline levels of $\mathrm{CD} 3+, \mathrm{CD} 4+$ and $\mathrm{CD} 4+/ \mathrm{CD} 8+$ cells after osteosarcoma resection [154]. This data may suggest that the combination of general/epidural anesthesia contributes to restoration of IL-2 and lymphocytes T helper after surgery. However, it must be noted that the study included children, who were unlikely randomized in the epidural group (no general anesthesia/sedation). Furthermore both the sample size and the statistical tests are questionable. It is also possible that the type of general anesthetic agent (intravenous vs. inhalational) may blunt the beneficial effects of epidural. In fact, propofol has shown to increase Th1/Th2 ratio and T-helper cells percentage respect to isoflurane in patients undergoing pulmonary lobectomy for non-smallcell lung cancer [155]. Several studies have shown that paravertebral analgesia enhances antitumorigenic cytokines, such as IL-10 [156] and decreases breast cancer function [157]. In particular, a retrospective analysis [158] investigated the recurrence-free survival time in patients undergoing breast cancer resection under general anesthesia with or without paravertebral analgesia. The paravertebral anesthesia group showed better tumor-free and metastasis-free survival compared to general anesthesia at 24 and 36 months (94\% vs. $82 \%$ and $87 \%$ vs. $77 \%$, respectively). Recently, women undergoing surgery for biopsy-proven primary breast were randomized to receive either TIVA with regional technique (paravertebral block) or general anesthesia with opioid (morphine) analgesia. Patients' serum was collected and exposed to estrogen receptor-negative breast cancer cells and cells apoptosis was measured. Women in the regional group showed higher breast cancer cells apoptosis ratios compared to patients who received balanced anesthesia with sevoflurane and morphine $(0.40$ vs. $0.22, \mathrm{P}=0.001)$ [159]. This data were confirmed in a another study [160] from the same institution, where TIVA with paravertebral block was associated to greater human donor NK cell cytotoxicity. Regional anesthesia has shown similar results after ovarian, colon and prostate surgery, but no in patients affected by melanoma [147].

Cata et al. [44] have recently reviewed over 140 studies to investigate the outcome of orthopedic oncologic surgical patients. Authors did not find any study suitable for metanalysis, but they confirmed the benefit of regional anesthesia in breast cancer recurrence. Moreover, they mentioned that little data exist in favor to regional anesthesia after gastrointestinal and genitourinary surgery.

In children data are lacking. Only few studies investigated the effect of anesthesia on children's immunity [58], and none regarding cancer recurrence. However, data have shown that the surgical stress has an important impact in the child's immunosuppression [161-163].

In children, regional anesthesia is almost always used in association to sedation or general anesthesia and has shown little or no benefits respect to opioids when associate to general anesthesia $[40,164,165]$.

On the contrary, spinal anesthesia is effective in reducing stress response after surgery (IL-6, IL-8, cortisol, catecholamines) [166].

In pediatric oncology, the only study in the literature suggests that a single dose of the combination of propofol/ketamine do not alter the immune system in children affected by acute lymphoblastic leukemia [167].

\section{Conclusions}

The balance between pro-inflammatory and anti-inflammatory cytokine has been shown to be critical in the tumor progression. By affecting this balance, anesthesia may play an important role on outcome of cancer patients.

Compared to general anesthesia alone, epidural and peripheral anesthesia may be beneficial in reducing cancer recurrence and should be considered whenever is possible. However, further investigations are needed to clarify the relation between anesthesia and cancer, particularly in children.

\section{Acknowledgments}

The present review has been funded by the Department of Anesthesia, McGill University Health Centre, Montreal Children's Hospital, Montreal, QC, Canada.

\section{References}

1. Sheeran P, Hall GM (1997) Cytokines in anaesthesia. Br J Anaesth 78: 201-219. [Crossref]

2. Enayati P, Brennan MF, Fong Y (1994) Systemic and liver cytokine activation. Implications for liver regeneration and posthepatectomy endotoxemia and sepsis. Arch Surg 129: 1159-1164. [Crossref] 
3. van der Poll T, Lowry SF (1995) Tumor necrosis factor in sepsis: mediator of multiple organ failure or essential part of host defense? Shock 3: 1-12. [Crossref]

4. Beutler B, Cerami A (1988) The common mediator of shock, cachexia, and tumor necrosis. Adv Immunol 42: 213-231. [Crossref]

5. Pujol-Borrell R, Todd I, Doshi M, Bottazzo GF, Sutton R, et al. (1987) HLA class II induction in human islet cells by interferon-gamma plus tumour necrosis factor or lymphotoxin. Nature 326: 304-306. [Crossref]

6. Waage A (1987) Production and clearance of tumor necrosis factor in rats exposed to endotoxin and dexamethasone. Clin Immunol Immunopathol 45: 348-355. [Crossref]

7. Dinarello CA (1991) Interleukin-1 and interleukin-1 antagonism. Blood 77: 16271652. [Crossref]

8. Dinarello CA (1991) The proinflammatory cytokines interleukin-1 and tumor necrosis factor and treatment of the septic shock syndrome. J Infect Dis 163: 1177-1184. [Crossref]

9. Molloy RG, Mannick JA, Rodrick ML (1993) Cytokines, sepsis and immunomodulation Br J Surg 80: 289-297. [Crossref]

10. Ohlsson K, Björk P, Bergenfeldt M, Hageman R, Thompson RC (1990) Interleukin-1 receptor antagonist reduces mortality from endotoxin shock. Nature 348: 550-552. [Crossref]

11. Xing Z, Gauldie J, Cox G, Baumann H, Jordana M, et al. (1998) IL-6 is an antiinflammatory cytokine required for controlling local or systemic acute inflammatory responses. J Clin Invest 101: 311-320. [Crossref]

12. Polgár A, Brózik M, Tóth S, Holub M, Hegyi K, et al. (2000) Soluble interleukin-6 receptor in plasma and in lymphocyte culture supernatants of healthy individuals and patients with systemic lupus erythematosus and rheumatoid arthritis. Med Sci Monit 6: 13-18. [Crossref]

13. Van Zee KJ, Fischer E, Hawes AS, Hébert CA, Terrell TG, et al. (1992) Effects of intravenous IL-8 administration in nonhuman primates. J Immunol 148: 1746-1752. [Crossref]

14. Finn A, Naik S, Klein N, Levinsky RJ, Strobel S, et al. (1993) Interleukin-8 release and neutrophil degranulation after pediatric cardiopulmonary bypass. J Thorac Cardiovasc Surg 105: 234-241. [Crossref]

15. Partrick DA, Moore FA, Moore EE, Biffl WL, Sauaia A, et al. (1996) Jack A Barney Resident Research Award winner. The inflammatory profile of interleukin-6, interleukin-8, and soluble intercellular adhesion molecule-1 in postinjury multiple organ failure. American journal of surgery 172: 425-429.

16. Gérard C, Bruyns C, Marchant A, Abramowicz D, Vandenabeele P, et al. (1993) Interleukin 10 reduces the release of tumor necrosis factor and prevents lethality in experimental endotoxemia. J Exp Med 177: 547-550. [Crossref]

17. Niiro H, Otsuka T, Kuga S, Nemoto Y, Abe M, et al. (1994) IL-10 inhibits prostaglandin E2 production by lipopolysaccharide-stimulated monocytes. Int Immunol 6: 661-664. [Crossref]

18. Buelens C, Willems F, Delvaux A, Piérard G, Delville JP, et al. (1995) Interleukin-10 differentially regulates B7-1 (CD80) and B7-2 (CD86) expression on human peripheral blood dendritic cells. Eur J Immunol 25: 2668-2672. [Crossref]

19. Lauw FN, Dekkers PE, te Velde AA, Speelman P, Levi M, et al. (1999) Interleukin-12 induces sustained activation of multiple host inflammatory mediator systems in chimpanzees. J Infect Dis 179: 646-652. [Crossref]

20. Alleva DG, Kaser SB, Monroy MA, Fenton MJ, Beller DI (1997) IL-15 functions as a potent autocrine regulator of macrophage proinflammatory cytokine production: evidence for differential receptor subunit utilization associated with stimulation or inhibition. J Immunol 159: 2941-2951. [Crossref]

21. McDonald PP, Russo MP, Ferrini S, Cassatella MA (1998) Interleukin-15 (IL-15) induces NF-kappaB activation and IL-8 production in human neutrophils. Blood 92: 4828-4835. [Crossref]

22. Sun RQ, Zhang SL (2011) The value of serum interleukin-18 and 10 in the evaluation of severity and prognosis in the early stage of sepsis. Zhongguo Wei Zhong Bing Ji Jiu Yi Xue 23: 299-301. [Crossref]

23. Roy I, Evans DB, Dwinell MB (2014) Chemokines and chemokine receptors: update on utility and challenges for the clinician. Surgery 155: 961-973. [Crossref]

24. Chouaib S, Chatenoud L, Klatzmann D, Fradelizi D (1984) The mechanisms of inhibition of human IL 2 production. II. PGE2 induction of suppressor T lymphocytes J Immunol 132: 1851-1857. [Crossref]

25. Waldmann TA (2006) The biology of interleukin-2 and interleukin-15: implications for cancer therapy and vaccine design. Nat Rev Immunol 6: 595-601. [Crossref]

26. Oka M, Hirazawa K, Yamamoto K, Iizuka N, Hazama S, et al. (1996) Induction of Fas-mediated apoptosis on circulating lymphocytes by surgical stress. Ann Surg 223 : 434-440. [Crossref]

27. Mosmann TR, Coffman RL (1989) TH1 and TH2 cells: different patterns of lymphokine secretion lead to different functional properties. Annu Rev Immunol 7: 145-173. [Crossref]

28. Kelly-Welch A, Hanson EM, Keegan AD (2005) Interleukin-4 (IL-4) pathway. Sci STKE 2005: cm9. [Crossref]

29. Chomarat P, Banchereau J (1998) Interleukin-4 and interleukin-13: their similarities and discrepancies. Int Rev Immunol 17: 1-52. [Crossref]

30. Etter H, Althaus R, Eugster HP, Santamaria-Babi LF, Weber L, et al. (1998) IL-4 and IL-13 downregulate rolling adhesion of leukocytes to IL-1 or TNF-alpha-activated endothelial cells by limiting the interval of E-selectin expression. Cytokine 10: 395403. [Crossref]

31. Fanning NF, Kell MR, Shorten GD, Kirwan WO, Bouchier-Hayes D, et al. (1999) Circulating granulocyte macrophage colony-stimulating factor in plasma of patients with the systemic inflammatory response syndrome delays neutrophil apoptosis through inhibition of spontaneous reactive oxygen species generation. Shock 11: 167174. [Crossref]

32. Kurosawa S, Kato M (2008) Anesthetics, immune cells, and immune responses. $J$ Anesth 22: 263-277. [Crossref]

33. Sanders RD (2014) III. Perioperative immunity: is there an anaesthetic hangover? $B r J$ Anaesth 112: 210-212. [Crossref]

34. Kaye AD, Patel N, Bueno FR, Hymel B, Vadivelu N, et al. (2014) Effect of opiates, anesthetic techniques, and other perioperative factors on surgical cancer patients. Ochsner J 14: 216-228. [Crossref]

35. Inada T, Yamanouchi Y, Jomura S, Sakamoto S, Takahashi M, et al. (2004) Effect of propofol and isoflurane anaesthesia on the immune response to surgery. Anaesthesia 59: 954-959. [Crossref]

36. Kelbel I, Weiss M (2001) Anaesthetics and immune function. Curr Opin Anaesthesiol 14: 685-691. [Crossref]

37. Klava A, Windsor AC, Farmery SM, Woodhouse LF, Reynolds JV, et al. (1997) Interleukin-10. A role in the development of postoperative immunosuppression. Arch Surg 132: 425-429. [Crossref]

38. Schneemilch CE, Ittenson A, Ansorge S, Hachenberg T, Bank U (2005) Effect of 2 anesthetic techniques on the postoperative proinflammatory and anti-inflammatory cytokine response and cellular immune function to minor surgery. $J$ Clin Anesth 17 517-527. [Crossref]

39. Jones RO, Anderson NH, Murchison JT, Brittan M, Simon EJ, et al. (2014) Innate immune responses after resection for lung cancer via video-assisted thoracoscopic surgery and thoracotomy. Innovations (Phila) 9: 93-103. [Crossref]

40. Vuori A, Salo M, Viljanto J, Pajulo O, Pulkki K, et al. (2004) Effects of post-operative pain treatment using non-steroidal anti-inflammatory analgesics, opioids or epidural blockade on systemic and local immune responses in children. Acta Anaesthesiol Scand 48: 738-749. [Crossref]

41. Galley HF, DiMatteo MA, Webster NR (2000) Immunomodulation by anaesthetic, sedative and analgesic agents: does it matter? Intensive Care Med 26: 267-274 [Crossref]

42. Homburger JA, Meiler SE (2006) Anesthesia drugs, immunity, and long-term outcome. Curr Opin Anaesthesiol 19: 423-428. [Crossref]

43. Young MJ, Alston TA (2012) Does anesthetic technique influence cancer? J Clin Anesth 24: 1-2. [Crossref]

44. Cata JP, Hernandez M, Lewis VO, Kurz A (2014) Can regional anesthesia and analgesia prolong cancer survival after orthopaedic oncologic surgery? Clin Orthop Relat Res 472: 1434-1441. [Crossref]

45. Tobias JD (2009) Inhalational anesthesia: basic pharmacology, end organ effects, and applications in the treatment of status asthmaticus. J Intensive Care Med 24: 361-371. [Crossref] 
46. Whalen FX, Bacon DR, Smith HM (2005) Inhaled anesthetics: an historical overview. Best Pract Res Clin Anaesthesiol 19: 323-330. [Crossref]

47. Nakagawara M, Takeshige K, Takamatsu J, Takahashi S, Yoshitake J, et al. (1986) Inhibition of superoxide production and $\mathrm{Ca} 2+$ mobilization in human neutrophils by halothane, enflurane, and isoflurane. Anesthesiology 64: 4-12. [Crossref]

48. Fröhlich D, Rothe G, Schwall B, Schmid P, Schmitz G, et al. (1997) Effects of volatile anaesthetics on human neutrophil oxidative response to the bacterial peptide FMLP. $\mathrm{Br}$ $J$ Anaesth 78: 718-723. [Crossref]

49. Welch WD (1981) Halothane reversibly inhibits human neutrophil bacterial killing. Anesthesiology 55: 650-654. [Crossref]

50. Tschaikowsky K, Ritter J, Schroppel K, Kuhn M (2000) Volatile anesthetics differentially affect immunostimulated expression of inducible nitric oxide synthase: role of intracellular calcium. Anesthesiology 92: 1093-1102. [Crossref]

51. Giraud O, Molliex S, Rolland C, Leçon-Malas V, Desmonts JM, et al. (2003) Halogenated anesthetics reduce interleukin-1beta-induced cytokine secretion by rat alveolar type II cells in primary culture. Anesthesiology 98: 74-81. [Crossref]

52. Boost KA, Flondor M, Hofstetter C, Platacis I, Stegewerth K, et al. (2007) The betaadrenoceptor antagonist propranolol counteracts anti-inflammatory effects of isoflurane in rat endotoxemia. Acta Anaesthesiol Scand 51: 900-908. [Crossref]

53. Schilling T, Kozian A, Senturk M, Huth C, Reinhold A, et al. (2011) Effects of volatile and intravenous anesthesia on the alveolar and systemic inflammatory response in thoracic surgical patients. Anesthesiology 115: 65-74. [Crossref]

54. Schilling T, Kozian A, Kretzschmar M, Huth C, Welte T, et al. (2007) Effects of propofol and desflurane anaesthesia on the alveolar inflammatory response to one-lung ventilation. Br J Anaesth 99: 368-375. [Crossref]

55. Mitsuhata H, Shimizu R, Yokoyama MM (1995) Suppressive effects of volatile anesthetics on cytokine release in human peripheral blood mononuclear cells. Int $J$ Immunopharmacol 17: 529-534. [Crossref]

56. Stevenson GW, Hall S, Miller PJ, Alvord G, Leventhal JB, et al. (1986) The effect of anesthetic agents on human immune system function. I. Design of a system to deliver inhalational anesthetic agents to leukocyte cultures in vitro. Journal of immunological methods 88: 277-83. [Crossref]

57. Mattila-Vuori A, Salo M, Iisalo E (1999) Immune response in infants undergoing application of cast: comparison of halothane and balanced anesthesia. Can J Anaesth 46: 1036-1042. [Crossref]

58. Siebert JN, Posfay-Barbe KM, Habre W, Siegrist CA (2007) Influence of anesthesia on immune responses and its effect on vaccination in children: review of evidence. Paediatr Anaesth 17: 410-420. [Crossref]

59. Melamed R, Bar-Yosef S, Shakhar G, Shakhar K, Ben-Eliyahu S (2003) Suppression of natural killer cell activity and promotion of tumor metastasis by ketamine, thiopental, and halothane, but not by propofol: mediating mechanisms and prophylactic measures. Anesth Analg 97: 1331-1339. [Crossref]

60. Brand JM, Kirchner H, Poppe C, Schmucker P (1997) The effects of general anesthesia on human peripheral immune cell distribution and cytokine production. Clin Immunol Immunopathol 83: 190-194. [Crossref]

61. Weimann J (2003) Toxicity of nitrous oxide. Best Pract Res Clin Anaesthesiol 17: 47-61. [Crossref]

62. Fleischmann E, Marschalek C, Schlemitz K, Dalton JE, Gruenberger T, et al. (2009) Nitrous oxide may not increase the risk of cancer recurrence after colorectal surgery: a follow-up of a randomized controlled trial. BMC Anesthesiol 9: 1. [Crossref]

63. Fahlenkamp AV, Coburn M, Rossaint R, Stoppe C, Haase H (2014) Comparison of the effects of xenon and sevoflurane anaesthesia on leucocyte function in surgical patients: a randomized trial. Br J Anaesth 112: 272-280. [Crossref]

64. Rossaint R, Reyle-Hahn M, Schulte Am Esch J, Scholz J, Scherpereel P, et al. (2003) Multicenter randomized comparison of the efficacy and safety of xenon and isoflurane in patients undergoing elective surgery. Anesthesiology 98: 6-13. [Crossref]

65. Jordan BD, Wright EL (2010) Xenon as an anesthetic agent. AANA J 78: 387-392. [Crossref]

66. de Rossi LW, Brueckmann M, Rex S, Barderschneider M, Buhre W, (2004) Xenon and isoflurane differentially modulate lipopolysaccharide-induced activation of the nuclear transcription factor KB and production of tumor necrosis factor-alpha and interleukin-6 in monocytes. Anesth Analg 98: 1007-1012.
67. Fahlenkamp AV, Coburn M, Haase H, Kipp M, Ryang YM, et al. (2011) Xenon enhances LPS-induced IL-1 $\beta$ expression in microglia via the extracellular signalregulated kinase 1/2 pathway. J Mol Neurosci 45: 48-59. [Crossref]

68. Ball C, Westhorpe R (2001) The history of intravenous anaesthesia: the barbiturates Part 2. Anaesthesia and intensive care 29: 219. [Crossref]

69. Stovner J, Endresen R (1965) Diazepam in intravenous anesthesia. Lancet 2: 12981299. [Crossref]

70. Reves JG, Fragen RJ, Vinik HR, Greenblatt DJ (1985) Midazolam: pharmacology and uses. Anesthesiology 62: 310-324. [Crossref]

71. Persson J (2013) Ketamine in pain management. CNS Neurosci Ther 19: 396-402. [Crossref]

72. Evans D, Turnham L, Barbour K, Kobe J, Wilson L, et al. (2005) Intravenous ketamine sedation for painful oncology procedures. Paediatr Anaesth 15: 131-138. [Crossref]

73. Forman SA (2011) Clinical and molecular pharmacology of etomidate. Anesthesiology 114: 695-707. [Crossref]

74. Fragen RJ, Shanks CA, Molteni A, Avram MJ (1984) Effects of etomidate on hormonal responses to surgical stress. Anesthesiology 61: 652-656. [Crossref]

75. Wagner RL, White PF (1984) Etomidate inhibits adrenocortical function in surgical patients. Anesthesiology 61: 647-651. [Crossref]

76. Kay B, Rolly G (1977) I.C.I. 35868, a new intravenous induction agent. Acto Anaesthesiol Belg 28: 303-316. [Crossref]

77. Gottschling S, Meyer S, Krenn T, Reinhard H, Lothschuetz D, et al. (2005) Propofo versus midazolam/ketamine for procedural sedation in pediatric oncology. J Pediatr Hematol Oncol 27: 471-476. [Crossref]

78. Pöpping DM, Elia N, Marret E, Wenk M, Tramèr MR (2009) Clonidine as an adjuvant to local anesthetics for peripheral nerve and plexus blocks: a meta-analysis of randomized trials. Anesthesiology 111: 406-415. [Crossref]

79. Ebert TJ, Hall JE, Barney JA, Uhrich TD, Colinco MD (2000) The effects of increasing plasma concentrations of dexmedetomidine in humans. Anesthesiology 93: 382-394. [Crossref]

80. Chen RM, Wu GJ, Tai YT, Sun WZ, Lin YL, et al. (2003) Propofol reduces nitric oxide biosynthesis in lipopolysaccharide-activated macrophages by downregulating the expression of inducible nitric oxide synthase. Archives of toxicology 77: 418-423. [Crossref]

81. Chen RM, Chen TG, Chen TL, Lin LL, Chang CC, et al. (2005) Anti-inflammatory and antioxidative effects of propofol on lipopolysaccharide-activated macrophages. Ann $N$ Y Acad Sci 1042: 262-271. [Crossref]

82. Hsing CH, Lin MC, Choi PC, Huang WC, Kai JI, et al. (2011) Anesthetic propofol reduces endotoxic inflammation by inhibiting reactive oxygen species-regulated $\mathrm{Akt} /$ IKKbeta/NF-kappaB signaling. PloS one 6: e17598. [Crossref]

83. Chen RM, Wu CH, Chang HC, Wu GJ, Lin YL, et al. (2003) Propofol suppresses macrophage functions and modulates mitochondrial membrane potential and cellular adenosine triphosphate synthesis. Anesthesiology 98: 1178-1185. [Crossref]

84. Devlin EG, Clarke RS, Mirakhur RK, McNeill TA (1994) Effect of four i.v. induction agents on T-lymphocyte proliferations to PHA in vitro. Br J Anaesth 73: 315-317. [Crossref]

85. Larsen B, Hoff G, Wilhelm W, Buchinger H, Wanner GA, et al. (1998) Effect of intravenous anesthetics on spontaneous and endotoxin-stimulated cytokine response in cultured human whole blood. Anesthesiology 89: 1218-1227. [Crossref]

86. Pirttikangas CO, Perttilä J, Salo M (1993) Propofol emulsion reduces proliferative responses of lymphocytes from intensive care patients. Intensive Care Med 19: 299302. [Crossref]

87. Jensen AG, Dahlgren C, Eintrei C (1993) Propofol decreases random and chemotactic stimulated locomotion of human neutrophils in vitro. Br J Anaesth 70: 99-100. [Crossref]

88. Heller A, Heller S, Blecken S, Urbaschek R, Koch T (1998) Effects of intravenous anesthetics on bacterial elimination in human blood in vitro. Acta Anaesthesiol Scand 42: 518-526. [Crossref]

89. Huettemann E, Jung A, Vogelsang H, Hout Nv, Sakka SG (2006) Effects of propofol vs methohexital on neutrophil function and immune status in critically ill patients. $J$ Anesth 20: 86-91. [Crossref] 
90. Galley HF, Dubbels AM, Webster NR (1998) The effect of midazolam and propofol on interleukin-8 from human polymorphonuclear leukocytes. Anesth Analg 86: 12891293. [Crossref]

91. Takaono M, Yogosawa T, Okawa-Takatsuji M, Aotsuka S (2002) Effects of intravenous anesthetics on interleukin (IL)-6 and IL-10 production by lipopolysaccharidestimulated mononuclear cells from healthy volunteers. Acta Anaesthesiol Scand 46: 176-179. [Crossref]

92. Taniguchi T, Kanakura H, Takemoto Y, Kidani Y, Yamamoto K (2003) Effects of ketamine and propofol on the ratio of interleukin-6 to interleukin-10 during endotoxemia in rats. Tohoku J Exp Med 200: 85-92. [Crossref]

93. Salo M, Pirttikangas CO, Pulkki K (1997) Effects of propofol emulsion and thiopentone on T helper cell type-1/type-2 balance in vitro. Anaesthesia 52: 341-344. [Crossref]

94. Kawasaki T, Ogata M, Kawasaki C, Ogata J, Inoue Y, et al. (1999) Ketamine suppresses proinflammatory cytokine production in human whole blood in vitro. Anesth Analg 89: 665-669. [Crossref]

95. Beilin B, Rusabrov Y, Shapira Y, Roytblat L, Greemberg L, et al. (2007) Low-dose ketamine affects immune responses in humans during the early postoperative period. Br J Anaesth 99: 522-527. [Crossref]

96. Kawasaki C, Kawasaki T, Ogata M, Nandate K, Shigematsu A. (2001) Ketamine isomers suppress superantigen-induced proinflammatory cytokine production in human whole blood. Can J Anaesth 48: 819-823. [Crossref]

97. Taniguchi T, Yamamoto K (2005) Anti-inflammatory effects of intravenous anesthetics on endotoxemia. Mini Rev Med Chem 5: 241-245. [Crossref]

98. Corrêa-Sales C, Tosta CE, Rizzo LV (1997) The effects of anesthesia with thiopental on $\mathrm{T}$ lymphocyte responses to antigen and mitogens in vivo and in vitro. Int $J$ Immunopharmacol 19: 117-128. [Crossref]

99. Nishina K, Akamatsu H, Mikawa K, Shiga M, Maekawa N, et al. (1998) The inhibitory effects of thiopental, midazolam, and ketamine on human neutrophil functions. Anesth Analg 86: 159-165. [Crossref]

100. Davidson JA, Boom SJ, Pearsall FJ, Zhang P, Ramsay G (1995) Comparison of the effects of four i.v. anaesthetic agents on polymorphonuclear leucocyte function. $\mathrm{BrJ}$ Anaesth 74: 315-318. [Crossref]

101. Devlin EG, Clarke RS, Mirakhur RK, McNeill TA (1994) Effect of four i.v. induction agents on T-lymphocyte proliferations to PHA in vitro. Br J Anaesth 73: 315-317. [Crossref]

102. Loop T, Liu Z, Humar M, Hoetzel A, Benzing A, et al. (2002) Thiopental inhibits the activation of nuclear factor kappaB. Anesthesiology 96: 1202-1213. [Crossref]

103. Nishina K, Akamatsu H, Mikawa K, Shiga M, Maekawa N, et al. (1999) The effects of clonidine and dexmedetomidine on human neutrophil functions. Anesth Analg 88: 452-458. [Crossref]

104. Kim Y, Kang SH2, Hong TH3, Cho ML4, Han HJ, et al. (2014) Effects of dexmedetomidine on the ratio of $\mathrm{T}$ helper 1 to $\mathrm{T}$ helper 2 cytokines in patients undergoing laparoscopic cholecystectomy. J Clin Anesth 26: 281-285. [Crossref]

105. Xiang H, Hu B, Li Z, Li J (2014) Dexmedetomidine controls systemic cytokine levels through the cholinergic anti-inflammatory pathway. Inflammation 37: 1763-1770. [Crossref]

106. Kosterlitz HW, Paterson SJ (1980) Characterization of opioid receptors in nervous tissue. Proc R Soc Lond B Biol Sci 210: 113-122. [Crossref]

107. Minami M, Satoh M (1995) Molecular biology of the opioid receptors: structures, functions and distributions. Neurosci Res 23: 121-145. [Crossref]

108. Sharp BM (2006) Multiple opioid receptors on immune cells modulate intracellular signaling. Brain Behav Immun 20: 9-14. [Crossref]

109. McCarthy L, Wetzel M, Sliker JK, Eisenstein TK, Rogers TJ (2001) Opioids, opioid receptors, and the immune response. Drug Alcohol Depend 62: 111-123. [Crossref]

110. Nouvelles JC (1898) Recherches sur le monde de destruction des vibrions dans l'organisme. Ann Inst Pasteur 12: 273-300.

111. Finley MJ, Happel CM, Kaminsky DE, Rogers TJ (2008) Opioid and nociceptin receptors regulate cytokine and cytokine receptor expression. Cell Immunol 252: 146154. [Crossref]

112. Ninkovic J, Roy S (2013) Role of the mu-opioid receptor in opioid modulation of immune function. Amino Acids 45: 9-24. [Crossref]

113. Hernandez MC, Flores LR, Bayer BM (1993) Immunosuppression by morphine is mediated by central pathways. J Pharmacol Exp Ther 267: 1336-1341. [Crossref]
114. Flores LR, Dretchen KL, Bayer BM (1996) Potential role of the autonomic nervous system in the immunosuppressive effects of acute morphine administration. European journal of pharmacology 318: 437-446. [Crossref]

115. Carr DJ, Rogers TJ, Weber RJ (1996) The relevance of opioids and opioid receptors on immunocompetence and immune homeostasis. Proc Soc Exp Biol Med 213: 248257. [Crossref]

116. Beltran JA, Peek J, Chang SL (2006) Expression and regulation of the mu opioid peptide receptor in TPA-differentiated HL-60 promyelocytic leukemia cells. International immunopharmacology 6: 1331-1340. [Crossref]

117. Sacerdote P, Limiroli E, Gaspani L (2003) Experimental evidence for immunomodulatory effects of opioids. Adv Exp Med Biol 521: 106-116. [Crossref]

118. Roy S, Wang J, Gupta S, Charboneau R, Loh HH, et al. (2004) Chronic morphine treatment differentiates $\mathrm{T}$ helper cells to Th2 effector cells by modulating transcription factors GATA 3 and T-bet. Journal of neuroimmunology 147: 78-81. [Crossref]

119. Vallejo R, de Leon-Casasola O, Benyamin R (2004) Opioid therapy and immunosuppression: a review. Am J Ther 11: 354-365. [Crossref]

120. Shavit Y, Ben-Eliyahu S, Zeidel A, Beilin B (2004) Effects of fentanyl on natural killer cell activity and on resistance to tumor metastasis in rats. Dose and timing study. Neuroimmunomodulation 11: 255-260. [Crossref]

121. Yeager MP, Procopio MA, DeLeo JA, Arruda JL, Hildebrandt L, et al. (2002) Intravenous fentanyl increases natural killer cell cytotoxicity and circulating CD16(+) lymphocytes in humans. Anesth Analg 94: 94-99, table of contents. [Crossref]

122. Jacobs R, Karst M, Scheinichen D, Bevilacqua C, Schneider U, et al. (1999) Effects of fentanyl on cellular immune functions in man. Int J Immunopharmacol 21: 445454. [Crossref]

123. Bilfinger TV, Fimiani C, Stefano GB (1998) Morphine's immunoregulatory actions are not shared by fentanyl. Int J Cardiol 64 Suppl 1: S61-66. [Crossref]

124. von Dossow V, Luetz A, Haas A, Sawitzki B, Wernecke KD, et al. (2008) Effect of remifentanil and fentanyl on the cell-mediated immune response in patients undergoing elective coronary artery bypass graft surgery. The Journal of international medical research 36: 1235-1247. [Crossref]

125. Courtney KR (1988) Local anesthetics. Int Anesthesiol Clin 26: 239-247. [Crossref]

126. Simpson D, Curran MP, Oldfield V, Keating GM (2005) Ropivacaine: a review of its use in regional anaesthesia and acute pain management. Drugs 65: 2675-2717. [Crossref]

127. Gordon SM, Mischenko AV, Dionne RA (2010) Long-acting local anesthetics and perioperative pain management. Dent Clin North Am 54: 611-620. [Crossref]

128. Nemec K, Cihal P, Timin E, Kamyar MR, Lemmens-Gruber R (2010) Evidence-based intravenous pain treatment with analgesic infusion regimens. Arzneimittelforschung 60: 256-261. [Crossref]

129. Lahav M, Levite M, Bassani L, Lang A, Fidder H, et al. (2002) Lidocaine inhibits secretion of IL- 8 and IL-1beta and stimulates secretion of IL-1 receptor antagonist by epithelial cells. Clin Exp Immunol 127: 226-233. [Crossref]

130. Cassuto J, Sinclair R, Bonderovic M (2006) Anti-inflammatory properties of local anesthetics and their present and potential clinical implications. Acta Anaesthesiol Scand 50: 265-282. [Crossref]

131. Kiefer RT, Ploppa A, Krueger WA, et al. (2003) Local anesthetics impair human granulocyte phagocytosis activity, oxidative burst, and CD11b expression in response to Staphylococcus aureus. Anesthesiology 98: 842-848. [Crossref]

132. Eriksson AS, Sinclair R, Cassuto J, Thomsen P (1992) Influence of lidocaine on leukocyte function in the surgical wound. Anesthesiology 77: 74-78. [Crossref]

133. Mikawa K, Akamatsu H, Nishina K, Shiga M, Maekawa N, et al. (1997) Inhibitory effect of local anaesthetics on reactive oxygen species production by human neutrophils. Acta Anaesthesiol Scand 41: 524-528. [Crossref]

134. Sinclair R, Eriksson AS, Gretzer C, Cassuto J, Thomsen P (1993) Inhibitory effects of amide local anaesthetics on stimulus-induced human leukocyte metabolic activation, LTB4 release and IL-1 secretion in vitro. Acta Anaesthesiol Scand 37: 159-165. [Crossref]

135. Yanagi H, Sankawa H, Saito H, Iikura Y (1996) Effect of lidocaine on histamine release and $\mathrm{Ca} 2+$ mobilization from mast cells and basophils. Acta Anaesthesiol Scand 40: 1138-1144. [Crossref]

136. Martinsson T, Oda T, Fernvik E, Roempke K, Dalsgaard CJ, et al. (1997) Ropivacaine 
inhibits leukocyte rolling, adhesion and CD11b/CD18 expression. J Pharmacol Exp Ther 283: 59-65. [Crossref]

137. Ramus GV, Cesano L, Barbalonga A (1983) Different concentrations of local anaesthetics have different modes of action on human lymphocytes. Agents and actions 13: 333-341. [Crossref]

138. Lang A, Ben Horin S, Picard O, Fudim E, Amariglio N, et al. (2010) Lidocaine inhibits epithelial chemokine secretion via inhibition of nuclear factor kappa B activation. Immunobiology 215: 304-313. [Crossref]

139. Lan W, Harmon DC, Wang JH, Shorten GD, Redmond PH (2005) Activated endothelial interleukin-1beta, -6 , and -8 concentrations and intercellular adhesion molecule-1 expression are attenuated by lidocaine. Anesth Analg 100: 409-412. [Crossref]

140. Lahat A, Ben-Horin S, Lang A, Fudim E, Picard O, et al. (2008) Lidocaine downregulates nuclear factor-kappaB signalling and inhibits cytokine production and $\mathrm{T}$ cell proliferation. Clin Exp Immunol 152: 320-327. [Crossref]

141. Feng G, Liu S, Wang GL, Liu GJ (2008) Lidocaine attenuates lipopolysaccharideinduced acute lung injury through inhibiting NF- $\mathrm{KB}$ activation. Pharmacology 81 : 32-40. [Crossref]

142. Blumenthal S, Borgeat A, Pasch T, Reyes L, Booy C, et al. (2006) Ropivacaine decreases inflammation in experimental endotoxin-induced lung injury. Anesthesiology 104: 961-969. [Crossref]

143. Høgevold HE, Lyberg T, Kähler H, Haug E, Reikerås O (2000) Changes in plasma IL1 beta, TNF-alpha and IL-6 after total hip replacement surgery in general or regional anaesthesia. Cytokine 12: 1156-1159. [Crossref]

144. Kehlet H (2000) Manipulation of the metabolic response in clinical practice. World $J$ Surg 24: 690-695. [Crossref]

145. Koltun WA, Bloomer MM, Tilberg AF, Seaton JF, Ilahi O, et al. (1996) Awake epidural anesthesia is associated with improved natural killer cell cytotoxicity and a reduced stress response. Am J Surg 171: 68-72. [Crossref]

146. Hole A, Unsgaard G (1983) The effect of epidural and general anaesthesia on lymphocyte functions during and after major orthopaedic surgery. Acta Anaesthesiol Scand 27: 135-141. [Crossref]

147. Tavare AN, Perry NJ, Benzonana LL, Takata M, Ma D (2012) Cancer recurrence after surgery: direct and indirect effects of anesthetic agents. Int J Cancer 130: 1237-1250. [Crossref]

148. Lin L, Liu C, Tan H, Ouyang H, Zhang Y, et al. (2011) Anaesthetic technique may affect prognosis for ovarian serous adenocarcinoma: a retrospective analysis. $\mathrm{Br} J$ Anaesth 106: 814-822. [Crossref]

149. Gupta A, Bjornsson A, Fredriksson M, Hallbook O, Eintrei C (2011) Reduction in mortality after epidural anaesthesia and analgesia in patients undergoing rectal but not colonic cancer surgery: a retrospective analysis of data from 655 patients in central Sweden. Br J Anaesth 107: 164-170. [Crossref]

150. de Oliveira GS, Ahmad S, Schink JC, Singh DK, Fitzgerald PC, et al. (2011) Intraoperative neuraxial anesthesia but not postoperative neuraxial analgesia is associated with increased relapse-free survival in ovarian cancer patients after primary cytoreductive surgery. Reg Anesth Pain Med 36: 271-277. [Crossref]

151. Procopio MA, Rassias AJ, DeLeo JA, Pahl J, Hildebrandt L, et al. (2001) The in vivo effects of general and epidural anesthesia on human immune function. Anesth Analg 93: 460-465. [Crossref]

152. Kurosawa S (2012) Anesthesia in patients with cancer disorders. Curr Opin Anaesthesiol 25: 376-384. [Crossref]

153. Cata JP, Bauer M, Sokari T, Ramirez MF, Mason D, et al. (2013) Effects of surgery, general anesthesia, and perioperative epidural analgesia on the immune function of patients with non-small cell lung cancer. J Clin Anesth 25: 255-262. [Crossref]

154. Wei L, Meng QG, Bi ZG (2013) Result of a randomized clinical trial comparing different types of anesthesia on the immune function of patients with osteosarcoma undergoing radical resection. Panminerva medica 55: 211-216. [Crossref]

155. Ren XF, Li WZ, Meng FY, Lin CF (2010) Differential effects of propofol and isoflurane on the activation of T-helper cells in lung cancer patients. Anaesthesia 65: 478-482. [Crossref]

156. Deegan CA, Murray D, Doran P, Moriarty DC, Sessler DI, et al. (2010) Anesthetic technique and the cytokine and matrix metalloproteinase response to primary breas cancer surgery. Reg Anesth Pain Med 35: 490-495. [Crossref]

157. Deegan CA, Murray D, Doran P, Ecimovic P, Moriarty DC, et al. (2009) Effect of anaesthetic technique on oestrogen receptor-negative breast cancer cell function in vitro. Br J Anaesth 103: 685-690. [Crossref]

158. Exadaktylos AK, Buggy DJ, Moriarty DC, Mascha E, Sessler DI (2006) Can anesthetic technique for primary breast cancer surgery affect recurrence or metastasis? Anesthesiology 105: 660-664. [Crossref]

159. Jaura AI, Flood G, Gallagher HC, Buggy DJ (2014) Differential effects of serum from patients administered distinct anaesthetic techniques on apoptosis in breast cancer cells in vitro: a pilot study. Br J Anaesth 113 Suppl 1: i63-67. [Crossref]

160. Buckley A, McQuaid S, Johnson P, Buggy DJ (2014) Effect of anaesthetic technique on the natural killer cell anti-tumour activity of serum from women undergoing breast cancer surgery: a pilot study. Br J Anaesth 113 Suppl 1: i56-62. [Crossref]

161. Kurz R, Pfeiffer KP, Sauer H (1983) Immunologic status in infants and children following surgery. Infection 11: 104-113. [Crossref]

162. Platt MP, Lovat PE, Watson JG, Aynsley-Green A (1989) The effects of anesthesia and surgery on lymphocyte populations and function in infants and children. J Pediatr Surg 24: 884-887. [Crossref]

163. Hauser GJ, Chan MM, Casey WF, Midgley FM, Holbrook PR (1991) Immune dysfunction in children after corrective surgery for congenital heart disease. Crit Care Med 19: 874-881. [Crossref]

164. Busoni P, Sarti A, De Martino M, Graziani E, Santoro S (1988) The effect of general and regional anesthesia on oxygen-dependent microbicidal mechanisms of polymorphonuclear leukocytes in children. Anesth Analg 67: 453-456. [Crossref]

165. Hansen TG, Tonnesen E, Andersen JB, Toft P, Bendtzen K (1998) The peri-operative cytokine response in infants and young children following major surgery. European journal of anaesthesiology 15: 56-60.

166. Wolf AR (2012) Effects of regional analgesia on stress responses to pediatric surgery. Paediatr Anaesth 22: 19-24. [Crossref]

167. Bertolizio G, Stucchi R, Sahillioglu E, Somaini M, Dander E, et al. (2013) The effects of propofol and ketamine on the cytokine levels of children with acute lymphoblastic leukemia. J Pediatr Hematol Oncol 35: e296-300. [Crossref]

Copyright: (C2015 Kitamura Y. This is an open-access article distributed under the terms of the Creative Commons Attribution License, which permits unrestricted use, distribution, and reproduction in any medium, provided the original author and source are credited. 